\title{
STRATEGI HUMAS UNTUK MEMPERBAIKI CITRA LEMBAGA PENDIDIKAN
}

\author{
Moh. Mashudi \\ IAIN Tulungagung
}

\begin{abstract}
Public relations serves as a distinctive management and supports the coaching, maintenance of the joint pathway between the organization and the public, concerning communication activities, understanding, acceptance and cooperation, involving management in dealing with problems, helping management to be able to face public opinion.

Creating a positive image for an institution or education, the role of Public Relations is also involved in many things such as making strategies and programs interesting to be able to compete and still exist both in a profit-oriented institutions and services to the community or nonprofit. The success of a Public Relations will determine the success or failure of vision and mission in an education or institution.

Looking at the above background contains the formulation of the problem: 1) How the public relations devinisi and research? 2) What is the negative and positive impact of public relations in educational institutions? 3) How to Step by step analysis of persuasive and contributive strategy in developing public relations in educational institutions.

The results of the theory analysis can be summarized as follows: 1) Public Relations is a typical management function, which supports coaching and maintenance, the joint path between the organization and its Public about communication, understanding and cooperation. Engage and assist management to know and respond to public opinion, establish and emphasize management's responsibility to serve the public as well as to support management in making positive use of experiments, using sound and ethical research and communication techniques as the primary means. 2) Negative influence, may occur due to ethical abuse in public relations activities and the positive influence that can result from the implementation of the code of ethics. 3) Steps - persuasive and contributive strategy in building Public Relations effectively by improving internal and external quality. So that Public Relations remain in good harmony with institutions and society.
\end{abstract}

Keywords: Public relations Strategy, Improving Education Institution image 


\begin{abstract}
ABSTRAK
Public relations berfungsi sebagai manajemen yang khas dan mendukung pembinaan, peneliharaan jalur bersama antara organisasi dengan publiknya, menyangkut aktivitas komunikasi, pengertian, penerimaan dan kerja sama, melibatkan manajemen dalam menghadapi persoalan atau permasalahan, membantu manajemen untuk mampu menghadapi opini public.

Menciptakan citra positif bagi sebuah institusi atau pendidikan, peran Public Relations juga dilibatkan dalam banyak hal seperti pembuatan strategi maupun program-program menarik untuk mampu bersaing dan tetap eksis baik dalam sebuah lembaga yang berorientasi profit maupun pelayanan pada masyarakat atau nonprofit. Keberhasilan seorang Public Relations akan menentukan sukses atau tidaknya visi dan misi dalam sebuah pendidikan atau lembaga.

Melihat latar belakang diatas mengandung rumusan masalah: 1) Bagaiman devinisi Public relations dan penelitian riset? 2) Bagaimana dampak negative dan positif public relations di lembaga pendidikan? 3) Bagaimana Langkah - langkah analisis strategi persuasive dan kontributif dalam membangaun public relations di lembaga pendidikan?

Hasil analisis teori dapat disimpulkan sebagai berikut: 1) Public Relations merupakan fungsi manajemen yang khas, yang mendukung pembinaan dan pemeliharaan, jalur bersama antara organisasi dan Publik-nya mengenai komunikasi, pengertian dan kerjasama. Melibatkan dan membantu manajemen agar tahu dan tanggap terhadap opini publik, menetapkan dan menekankan tanggung jawab manajemen agar melayani publik maupun mendukung manajemen dalam memanfaatkan percobaan secara positif-efektif, menggunakan teknik penelitian dan komunikasi yang sehat dan etis sebagai sarana utama. 2) Pengaruh negatif, mungkin terjadi akibat penyalah gunaan etika dalam kegiatan PR dan pengaruh positif yang dapat ditimbulkan akibat dijalankannya kode etik. 3) Langkah - Langkah strategi persuasive dan kontributif dalam membangun Public Relations secara efektif dengan cara meningkatkan kualitas internal dan eksternal. Sehingga Public Relations tetap harmonis baik dengan lembaga dan masyarakat.
\end{abstract}

Kata Kunci : Strategi Humas, Memperbaiki Citra Lembaga Pendidikan 


\section{A. PENDAhULUAN}

Peran seorang Public Relations dan penelitian saat ini sangat penting dalam sebuah institusi atau pendidikan. Public relations dalam pendidikan merupakan ujung tombak sehingga perannya menjadi sangat penting dan strategis. Selain untuk menciptakan citra positif bagi sebuah institusi atau pendidikan, peran PR juga dilibatkan dalam banyak hal seperti pembuatan strategi maupun program-program menarik untuk mampu bersaing dan tetap eksis baik dalam sebuah lembaga yang berorientasi profit maupun pelayanan pada masyarakat atau nonprofit. Keberhasilan seorang PR akan menentukan sukses atau tidaknya visi dan misi dalam sebuah pendidikan atau lembaga.

Public relations berfungsi sebagai manajemen yang khas dan mendukung pembinaan, peneliharaan jalur bersama antara organisasi dengan publiknya, menyangkut aktivitas komunikasi, pengertian, penerimaan dan kerja sama, melibatkan manajemen dalam menghadapi persoalan/permasalahan, mambantu manajemen untuk mampu menghadapi opini publik, mendukung manajemen dalam mengikuti dan memanfaatkan perubahan secara efektif, bertindak sebagai peringatan dini dalam mengantisipasi kecenderungan penggunaan penelitian serta teknik komunikasi yang sehat dan etis sebagai sarana utama.untuk itu peran Public Relations sangat penting dalam sebuah pendidikan (Abdurrachman: 2001: 34).
B. PUBLIC

RELATION

DAN

\section{PENELITIAN}

\section{Public Relation}

Menurut Ruslan dalam bukunya 'Manajemen Public Relations dan Media Komunikasi', peranan public relation dalam sebuah organisasi atau pendidikan berkaitan dengan tujuan utama dan fungi-fungsi manajemen pendidikan. Fungsi dasar manajemen tersebut merupakan suatu proses kegiatan atau pencapaian suatu tujuan pokok dari organisasi lembaga yang biasanya berkaitan dengan memanfaatkan berbagai potensi sumber-sumber (sumberdaya yang ada) yang dimiliki oleh organisasi atau lembaga terebut. Sumber daya tersebut meliputi sumber daya Manusia (Men), sumber Material/barang yang dikuasai (Material), alat atau pekakas mesin produksi yang dimiliki (Machine), kemampuan keuangan (Money), Metode yang digunakan (Methode), dan perluasan atau pemasaran yang hendak dicapai atau dituju (Market). Sumber daya tersebut dinamakan 6-M (Rosyadi, 2008: 25).

Dalam landasan manajemen dalam Al qura'an dijelaskan firman Allah SWT dalam surah An Nahl (16:64) sebagai berikut :

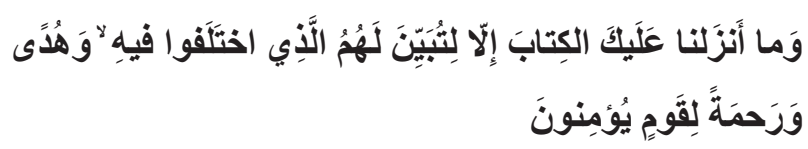


"Dan kami tidak menurunkan kepadamu Al-Kitab (Al-Qur'an) ini, melainkan agar kamu dapat menjelaskan kepada mereka apa yang mereka perselisihkan itu dan menjadi petunjuk dan rahmat bagi kamu yang beriman.

Keterangan di atas menandakan bahwa manajemen berlandasan Al Qur'an untuk meyaqinkan manusia agar lembaganya lebih terarah. Keberhasilan peran PR dalam menunjang fungsi-fungsi manajemen pendidikan untuk mencapai tujuan bersama tergantung pada kemampuan memanfaatkan unsur-unsur sumber daya yang dimiliki pada sebuah organisasi atau lembaga tersebut, artinya sebagai public relations manajer dituntut kemampuannya untuk mengorganisasikan seluruh unsur sumber daya yang ada (Rosyadi, 2008: 45).

\section{Penelitian}

Dalam Hadist di terangkan :

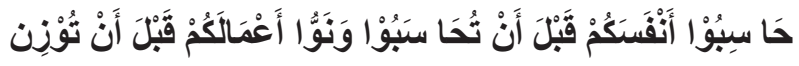

"Periksalah dirimu sebelum memeriksa orang lain. Lihatlah terlebih dahulu atas kerjamu sebelum melihat kerja orang lain.” (HR. Tirmidzi: 2383)

Dalam pandangan Islam segala sesuatu harus dilakukan secara terencana, dan teratur. Tidak terkecuali dengan proses dalam menerapkan seluruh program dalam renstra ini merupakan hal yang harus diperhatikan, karena substansi dari proses adalah membantu pengambil kebijakan agar mereka dapat membuktikan seluruh perencanaan itu secara baik dan maksimal. Rasul bersabda :

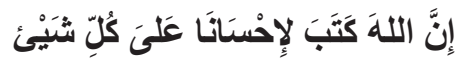

"Sesungguhnya mewajibkan kepada kita untuk berlaku ihsan dalam segala sesuatu.” (HR. Bukhari: 6010).

Berdasarkan hadits di atas, pengawasan dalam Islam dilakukan untuk meluruskan yang bengkok, mengoreksi yang salah dan membenarkan yang hak. Dalam renstra ini, melihat perkembangan dunia selalu membawa perubahan sehingga mengharuskan para manusia mengikuti perubahan itu dengan tetap memperhatikan antara kebaikan dan keburukan serta dapat menyaring setiap budaya-budaya yang muncul.

\section{DAMPAK NEGATIF DAN POSITIF PUBLIC RELATIONS DI LEMBAGA PENDIDIKAN}

Peran fasilitator komunikasi bagi seorang praktisi adalah sebagai pendengar yang peka dan broker (perantara) komunikasi. Menengahi interaksi, menyusun agenda mendiagnosis dan memperbaiki kondisi-kondisi yang menganggu hubungan komunikasi di antara kedua belah pihak. Fasilitator komunikasi 
menempati peran di tengah-tengah dna berfungsi sebagai penghubung antara organisasi dan publik.

Pengaruh positif yang dapat ditimbulkan akibat dijalankannya kode etik ini adalah sebagai berikut: (Riantara, 2004:

1. Humas dapat meningkatkan praktek profesionalisme dengan memberikan kode

etik dan memberdayakan perilaku dan kinerja yang bersifat etis dan standar

2. Humas mampu meningkatkan perilaku dari suatu organisasi dengan menekankan pada kebutuhan akan aspirasi masyarakat

3. Humas mampu melayani kepentingan masyarakat dengan menyerap aspirasi yang berkembang di tengah masyarakat

4. Humas melayani kelompok masyarakat tertentu dan masyarakat lainnya dengan menggunakan komunikasi dan media untuk mengubah informasi yang tidak benar menjadi informasi yang sebenarnya.

5. Humas mempengaruhi tanggung jawab sosialnya dengan mendukung kesejahteraan manusia dengan cara memperbaiki sistem sosial yang disesuaikan dengan perubahan kebutuhan dan lingkungan.
Selain itu, juga terdapat beberapa pengaruh negatif, mungkin terjadi akibat penyalah gunaan etika dalam kegiatan PR, seperti (Kasali, 2003: 35)

1. Humas yang ingin mendapatkan keuntungan dengan mendukung kepentingan tertentu, kadang-kadang sampai mengorbankan kepentingan masyarakat.

2. Humas ada kalanya membuat kekacauan dalam saluran-saluran komunikasi dengan membuat informasi menjadi lebih rumit dan membingungkan daripada bersifat klarifikasi.

3. Humas dapat mengakibatkan rusaknya kredibilitas dan saluran komunikasi karena dinodai oleh rasa kebencian dan sinisme.

Selain pengaruh negatif diatas, seringkali kegiatan-kegiatan yang dilakukan PR berujung pada penuntutan melalui jalur hukum, oleh pihak-pihak yang merasa tidak puas. Karena itu, PR lembaga pemerintah juga dituntut untuk "melek" hukum dalam melakukan aktifitasnya. Minimal mengetahui dan memahami kegiatankegiatan mereka yang berpotensi dalam pelanggaran hukum. 
D. LANGKAH ANALISIS STRATEGI PERSUASIVE DAN KONTRIBUTIF DALAM MEMBANGUN PUBLIC RELATIONS

\section{Strategi Persuasive}

Menganalisis strategi humas di lembaga pendidikan sangatlah penting, untuk mengevaluasi kegiatan baik di internal atau eksternal, untuk membangun Public relations. Maka ada langkah langkah persuasive yang mempunyai ciriciri sebagai berikut : (Kasali, 2003: 33)

a. Informasi atau pesan yang disampaikan harus berdasarkan pada kebutuhan atau kepentingan khalayak sebagai sasarannya.

b. PR sebagai komunikator dan sekaligus mediator berupaya membentuk sikap, dan pendapat yang positif dari masyarakat melalui rangsangan atau stimulasi tertentu.

c. Mendorong publik untuk berperan serta dalam aktivitas perusahaan atau organisasi, agar tercipta perubahan sikap dan penilaian (perubahan dari situasi negatif diubah menjadi situasi yang positif)

d. Perubahan sikap dan penilaian dari pihak publik dapat terjadi maka pembinaan dan pengembangan terus menerus diakukan agar peran serta tersebut terpelihara dengan baik.
Seorang praktisi public relations atau humas memiliki tugas tidak hanya sebagai pembentuk citra positif, melainkan sebagai fungsi manajemen suatu perusahaan. Fungsi manajemen didasarkan pada analisis terhadap pengaruh yang kuat dari lingkungan, apa efek dan dampaknya terhadap publik internal maupun eksternal. Merencanakan suatu kegiatan dan peraturan untuk direalisasikan, dengan tujuan memperoleh keuntungan dua belah pihak (Rumanti, 2002: 12).

\section{Strategi Kontributif}

Strategi kontributif dalam membangun citra lembaga pendidikan membutuhkan kolaborasi antara sistem internal dan eksternal yang menghasilkan tujuan humas.

\section{a. Hubungan dengan public Intern}

1) Hubungan dengan karyawan

Fungsi humas berkisar pada kegiatan menciptakan dan mewujudkan hubungan yang harmonis antara pimpinan organisasi dengan karyawan. Ini dilakukan dengan membinas hubungan yang sudah baik dan upaya mencegah terjadinya hubungan yang retak dan ini dilaksanakan dengan komunikasi.

2) Hubungan dengan pemegang lembaga

Pembinaan merupakan kegitan komunikasi yang menjadi tugas 
kahumas (Stakeholder relation) antara

lain sebagai berikut : (Rumanti, 2002:
a. Menyatakan selamat pada pemegang saham baru
b. Mengirimkan berkala organisasi
c. Menyampaikan laporan tahunan

\section{b. Hubungan dengan public ekstern}

Publik ekstern sebagai sasaran humas tersdiri atas orang-orang/ masyarakat di luar organisasi,baik yang ada kaitannya dengan organisasi maupun yang diharapkan/ diduga ada kaitannya dengan organisasi.

\section{Hubungan dengan Pelanggan}

Pekerjaaan humas tidak hanya berjisar pada kegiatan publikasi, tetapi juga kegiatan penyelidikan yang tidak jauh berbeda dengan spionase. Dengan terlibatnya kahumas dalam perang propaganda antara perusahaanperusahaan saingannya, ia harus cekatan dan terampil dalam berkomunikasi dan dalam memantau kegiatan lawan.

\section{Hubungan dengan Komunitas}

Hubungan masyarakat yang merupakan partisipasi suatu lembaga yang berencana, aktif dan sinambung dengan dan didalam suatu komunitas untuk memelihara dan membina lingkungannya demi keuntungan dua pihak, lembaga dan komunitas. Dalam hal ini kahumas sebagai pelaksanaanya yang bersifat partisipatif (Rumanti, 2002: 36).

\section{Hubungan dengan pemerintah}

a) Menguasai peraturan-peraturan pemerintah (Rumanti, 2002: 36).

b) Membina hubungan dengan instansi pemerintah.

Maksudnya adalah mengakrabkan diri dengan pimpinan instansi pemerintah setempat, setidak-tidaknya dengan humas instansi yang bersangkutan. Tujuan Pembinaan itu adalah, disatu pihak untuk melancarkan hubungan kerja bilamana suatu ketika diperlukan, memperlicin permohonan kalau suatu waktu diajukan, mempermudah pemecahan masalah jika suatu asat terjadi salah pengertian.

\section{Hubungan dengan media massa}

Maknanya adalah terbinanya hubungan kahumas dengan orang-orang media massa, seperti redaktur surat kabar dan majalah, wartawan televisi dan radio atau reporter televisi.

Pers khususnya dan media massa umumnya dapat dimanfaatkan oleh kahumas dengan berbagai cara antara lain dengan :
a. Jumpa pers (Press Conference)
b. Wisata pers (Press Tour)
c. Siaran pers (Press Release) : Siaran pers mencakup publisitas amat penting 
dalam kehumasan karena informasi diseberluaskan oleh media massa tanpa membayar sama sekali (Rumanti, 2002: 45).

d. Periklanan (Advertising) : Kehumas perlu membayar jika memasang iklan

$$
\text { Sikap kahumas yang }
$$

menunjukkan rasa simpati dam empati kepada insane-insan media dengan menyentuh manusiawinya akan membuat kedua pihak menjadi akrab yang pada gilirannya akan menimbulkan keuntungan pada organisasi yang diwakili kahumas itu.

Strategi manajemen humas agar kontribusinya lebih maksimal, maka melalui sebagai berikut:

\section{Prinsip-Prinsip Manajemen Humas}

Menurut Tim Pakar Manajemen Pendidikan, beberapa prinsip yang perlu diterapkan dalam meningkatkan keterlibatan masyarakat dalam bidang pendidikan menitikberatkan pada lembaga pendidikan yang mampu berkomunikasi secara aktif dengan masyarakat. Untuk itu perlu penerapan beberapa prinsip, yaitu:

\section{a. Fleksibilitas}

Lembaga pendidikan hendaknya mempunyai program yang cukup lentur dan beradaptasi secara terus menerus dengan perubahan-perubahan layanan lembaga lain di masyarakat.
Perkembangan tuntutan masyarakat, pengetahuan, teknolgi yang begitu cepat perlu diikuti dengan program pendidikan yang relevan. Misalnya perkembangan teknologi komunikasi dalam era globalisasi yang sekarang sedang terjadi.

\section{b. Relevansi}

Peran dan fungsi lembaga pendidikan hendaknya ditentukan sesuai dengan kondisi masyarakat yang menjadi latar belakang peserta didik. Hali ini perlu diperhatikan karena anak setelah menyelesaikan studi akan kembali ke masyarakat sebagai pengguna lulusan suatu lembaga pendidikan.

\section{c. Partisipasi}

Lembaga pendidikan bersama masyarakat hendaknya mengembangkan program kegiatan dan layanan guna memperluas, memperbarui, memadukan pengalaman berbagai kelompok umur pada semua tingkatan. Lembaga pendidikan perlu memperhatikan kebutuhan masyarakat ini.

\section{d. Komprehensi}

Lembaga pendidikan harus selalu menghubungkan dirinya dengan masyarakat yang lebih luas, interen bangsa maupun secara internasional. Hal ini perlu dilakukan karena era global sudah mulai terjadi. Lulusan tidak hanya dipersiapkan untuk interen (lokal) tapi bisa diperluas 
sesuai dengan kebutuhan (Rumanti, 2002: 35).

\section{e. Melembaga}

Layanan efektif dalam masyarakat pada setiap warga Negara hanya dapat dicapai melalui organisasi, terutama organisasi pendidikan yang dikelola secara baik dalam memaksimalkan partisipasi masyarakat, kegiatannya perlu diorganisasi secara baik (Kusumastuti, 2001: 31).

\section{Merealisasikan Program Manajemen}

\section{Humas}

Sesuai peranannya sebagai

pengabdi untuk kepentingan umum, sebagai mediator antara pimpinan dengan publik, dan sebagai dokumentator, maka program humas menitikberatkan pada:

a. Program Pelayanan

Program ini berupa layanan data/informasi baik secara lisan maupun tertulis, termasuk penyelenggaraan display tetap dan pameran.

b. Program Mediator

Program ini berupa penerbitan berbagai media masa, penyelenggaraan konverensi pers, wisata pers, menjawab surat pembaca, menanggapi tajuk rencana yang negatif dan lain-lain.

c. Program Dokumentator
Program ini berupa pembuatan dokumentasi film, foto rekaman (kaset, audio dan video), transkrip pidato dan lain-lain (Rumanti, 2002: $55)$.

\section{Proses Pelaksanaan Tugas Humas}

Menurut Widjaja menyebutkan bahwa proses pelaksanaan tugas Humas terdiri dari:

1. Menyelidiki dan mendengar (fact finding) Taraf research-listening atau fact-finding; meliputi penelitian pendapat, sikap dan reaksi orangorang atau publik.disini dapat diketahui masalah apa yang sedang dihadapi.

2. Mengambil ketentuan dan merencanakan (planning) setelah pendapat, sikap dan reaksi publik dianalisa, lalu diintegrasikan atau diserahkan dengan kebijaksanaan dan kegiatan organisasi. Pada taraf ini bisa ditemukan "pilihan yang diambil".

3. Melaksanakan komunikasi (coomunicating) Rencana-rencana diatas harus dikomunikasikan dengan semua pihak yang bersangkutan dengan metode yang sesuai. Dalam tahap ini kita “menerangkan (menjelaskan) tindakan yang diambil dan apa alasan jatuhnya pilihan tersebut". 
4. Penilaian (evaluation) dinilai segisegi berhasil atau tidaknya, apa sebab-sebabnya, apa yang sudah dicapai, apa resep kemanjurannya dan apa faktor penghambatnnya. Bagaimana hasil pelaksanaan tugas dan apa sebab-sebabnya "itulah pertanyaan yang timbul dalam tahap ini (Widjaja, 2004: 22).

\section{Analisis Sumber Daya Manusia}

Dalam rangka analisis sumber daya yaitu dengan Peningkatan ketersediaan sumber daya manusia yang mumpuni di bidangnya masing-masing dengan melihat sisi yang perlu disediakan sebagai berikut:

a. Tersedianya pengurus lembaga pendidikan baik dari pihak yayasan maupun pihak lembaga yang profesional di bidang masing-masing

b. Tersedianya lembaga khusus di bidang penjaminan mutu untuk lembaga pendidikan

c. Tersedianya wahana pelatihan keprofesionalan seluruh pihak yang menjadi bagian di lembaga pendidikan.

\section{Analisis Sumber Daya Keuangan}

Dalam rangka analisis sumber daya keuangan dengan peningkatan pendapatan pada lembaga pendidikan lembaga pendidikan ini dengan melihat sisi yang perlu disediakan sebagai berikut : (Rumanti, 2002: 45)

a. Adanya sumber keuangan yang mampu menjamin biaya operasional lembaga pendidikan setiap harinya bahkan sudah terencana jauh ke depan

b. Tersedianya sumber keuangan yang berasal dari usaha khusus yang dikelola oleh pihak tertentu lembaga pendidikan seperti usaha mini-market, peternakan atau perikanan

c. Tersedianya kerjasama di bidang jasa dengan berbagai pihak yang dianggap sesuai dengan visi, misi dan tujuan berdirinya Lembaga pendidikan Alikhlas Ujung-Bone ini.

d. Tersedianya system pelaporan keuangan yang transparansi agar tidak terjadi saling kecurigaan dalam mengelola keuangan tersebut.

e. Adanya kerjasama dengan pihak bankbank yang mempunyai misi sosial yang tinggi dalam menyediakan beasiswa-beasiswa khusus untuk santri/santriwati yang yatim-piatu atau yang berprestasi.

\section{Analisis Sumber Daya Sarpras}

Dalam rangka analisis sumber daya Sarpras (saran dan prasarana) yaitu dengan peningkatan ketersediaan prasarana dan sarana pendidikan yang bermutu, 
dengan melihat sisi yang perlu disediakan sebagai berikut : (Rumanti, 2002: 23)

a. Tersedianya manajemen penyediaan prasarana dan sarana pendidikan lembaga yang sistematis

b. Tersedianya prasarana dan sarana pembelajaran umum yang bermutu.

c. Tersedianya prasarana dan sarana pembelajaran khusus yang bermutu.

d. Tersedianya prasarana dan sarana penunjang yang bermutu.

e. Tersedianya Prasarana dan sarana yang berteknologi tinggi tapi tetap bernuangsa alami.

\section{Analisis Masalah dan Hambatan}

Dalam rangka analisis Masalah dan Hambatan ini dapat dilihat dengan adanya ketersediaan penyelesaian masalah sebagai berikut : (Buchori, 2008:

a. Tersedianya tim yang mampu mengevaluasi sistem manajemen yang sedang berjalan dari awal sampai akhir suatu program atau kegiatan-kegiatan.

b. Adanya penyeleksian pengurus /guru/pegawai dalam penempatan keahlian mereka masing-masing yang sesuai bidangnya. Dan penambahan jumlah guru atau pegawai supaya dapat memenuhi kouta perbandingan 1:20 (SDM : Santri/ Santriwati). c. Rutinnya pelatihan teknologi informasi dan komunikasi (TIK) dikalangan pengurus/guru/pegawai bahkan kepada santri/santriwati.

d. Rutinnya pertemuan antara para guru dan pengurus serta pegawai dalam hal membahas permasalahanpermasalahan seputar lembaga dan sekitarnya bahkan permasalahan global.

e. Rutinnya pelatihan karya tulis ilmiah sebagai dasar para guru dan santri dalam mengembangkan minat tulismenulis serta semangat dalam membaca.

f. Penggunaan sumber daya yang dimiliki dengan efisien dan semaksimal mungkin.

\section{Analisis Penyelesaian Masalah.}

Adapun syarat, metode atau cara penyelesaian masalah yang dapat diterapkan sebagai berikut : (Machali, 2010: 28)

a. Syarat yang harus dimiliki oleh Problem solver (sebagai orang yang menyelesaikan masalah) yaitu: Kecerdasan dalam mengetahui jenis permasalahan, Perancangan dari berbagai alternatif solusi dan Pemilihan solusi serta peluang.

b. Metode atau cara yang digunakan dalam menyelesaikan masalah dalam pondok lembaga pendidikan ini yaitu : 
1. Konsiliasi, untuk menengahkan dan mencari persetujuan dan penyelesaian

2. Mediasi, melibatkan pihak ketiga dalam masalah sebagai penasehat

3. Arbitrasi, menyerahkan keputusan dari mereka yang berselisih kepada pihak ketiga

4. Adjudication, penyelesaian dengan melibatkan pengadilan dalam hal sengketa yang tidak bisa diselesaikan dengan baik dan ini pun sudah berusaha dalam berbagai cara yang dianggap bisa untuk menyelesaikan permasalahan dan konflik yang dihadapi (Taufiq, 2017: 34).

Langkah - langkah di atas sebagai analisis strategi untuk menjaga citra humas di lembaga, karena humas sangatlah penting untuk sebuah lembaga pendidikan Islam yang berkontribusi pada Agama dan bangsa. Sedangkang menganalisis semua strategi program humas dan sistem lambaga, berkontribusi untuk mengevaluasi citra out pout lembaga tersebut.

\section{E. HASIL PENELITIAN DAN PEMBAHASAN}

\section{Deskripsi Data}

Berdasarkan hasil interview dan sumber data dokumenter berupa buku tentang sejarah berdirinya Pondok Pesantren Nasyrul ulum yang disusun oleh almarhum KH. A. Zaenuddin bahwa Pondok Pesantren Nasyrul Ulum berada di Desa Modangan Kecamatan Nglegok Kabupaten Blitar, berdiri resmi pada tahun 1918 M. Dengan mendapat pengesahan dari Pemerintah Belanda (penjajah) pada waktu itu.

Seorang Ulama' yang kebetulan menjabat sebagai Penghulu di Yogyakarta pada tahun 1917 M. Yang bernama R.K.H. Abu Said dengan alamat Jombokan, Wates, Yogyakarta mempunyai anak. Diantaranya dua anak lakilakinya bernama Abu Syukur dan yang seorang lagi bernama Manshur.

Dalam sebuah buku catatan yang sampai sekarang masih tersimpan rapi, bahwa R.K.H Abu Said mempunyai silsilah garis keturunan sampai dengan Nabi Muhammad SAW. Dan benar tidaknya hanya Allah sajalah Yang Maha Tahu segalanya.

Pada tahun 1918 Mansyur mendirikan pondok pesantren Nasyrul Ulum (dengan memakai sh : ص dalam kata Nasyrul Ulum) dengan mendapatkan pengesahan dari pemerintah Belanda. Tujuan berdirinya pondok pesantren ini menurut almarhum Kyai $H$. A.Zaenuddin sangat berkaitan dengan sejarah yang sedikit telah disinggung dimuka yaitu keadaan masyarakat yang sudah rusak moralitas dan meningkatkan Visi - Misi pendidikan Nasional . 


\section{Temuan Penelitian}

Wawancara pada penelitian strategi dalam membangaun Public relations di lembaga pendidikan PP. Nasyrul Ulum Modangan,

Menurut beliau pengasuh Drs. KH. M Lubbul "aqil kegiatan Pondok Pesantren untuk membangun Public relations ada dua cara yaitu bidang internal dan eksternal.

\section{a. Internal}

Membangun Public relations di Pondok Pesantren Nasyrul Ulum Modangan Nglegok Blitar, dengan meingkatkan internalnya. Karena Public relations dalam masyarakat melihat dari out put yang maksimal, sebab proses internal yang matang.

Dalam mengatasi era modern ini pondok pesantren harus mengembangkan program-programnya, seperti yang diungkapkan oleh KH. Drs. M. Lubbul Aqil“maka usaha yang dilakukan pondok pesantren dan para Kyai, Asatidznya adalah melakukan strategi pendidikan secara kontinyu, diskusi, praktek, baik pelajaran pokok, pelajaran harian dan pendidikan Lafe sekill." Oleh sebab itu adanya kegiatan para santri yang sangat di butuhkan masyarakat. Maka Kyai / pengasuh pondok pesantren meningakatkan dari kegiatan dan pokok pokok pendidikan yaitu :

\section{a) Meningkatkan Kurikulum.}

Pembelajaran pendidikan pondok pesantren Nasyrul Ulum, selain mengkaji kitab kuning, juga ada lembaga Madrasah Diniyah yaitu Diniyah nahariyah, diniyyah lailiyyah. Untuk Diniyah nahariyah dalam pembelajaranya pada waktu shore mulai jam $14.00 \mathrm{~s} / \mathrm{d}$ 16.00. WIB serta diwajibkan mengikuti bagi santri yang khusus mondok tidak mengikuti pendidikan formal, seperti MTs / MA/ SMK. Sedangkan Diniyyah Lailiyyah pembelajarannya mualai malam hari jam $19.00 \mathrm{~s} / \mathrm{d}$ 21.00. WIB, yang dikhususkan kepada santri yang mengikuti formal. Adapun evaluasinya ujian harian, triwulanan ujian semesteran atau Imtihan nishfi sanah dan akhir sanah.

\section{b) Meningkatkan Sarana dan Prasarana}

Sarana prasa santri yaitu meliputi, Masjid, asrama, toilet, kantor pondok, kantin, garasi sepedah motor, mobil media pembelajaran, LCD, proyektor, laptop, perpustakaan, toko kitab dan peralatan ATK.

\section{c) Tenaga pendidikan}

Sebagai tenaga pendidikan seharusnya memiliki kemandirian serta kebijakan yang luas, jauh dari intervensi, pelatihan-pelatihan tentang prinsip-prinsip kependidikan secara umum secara bertahap, memiliki keluasan dalam pengelolaan manajemen pesantren. 
d) Pengembangan

Anggaran

Pondok

\section{Pesantren}

Sesuai dengan perjalanan keuangan yang ada "angaran pesantren selama ini dari swadaya para santri dan bekerjasama dengan pemerintah Kabupaten Blitar dan Wilayah yaitu BOSDA Madin dan pihak alumni / mutakhorijin."

\section{e) Prosedur Peraturan Pondok Pesantren}

Secara peraturan setrukturalnya pesantren dibawah naungan Kemenag akan tetapi secara kurikulum pendidikan sifatnya mandiri, sesuai ketentuan pesantren.

\section{f) Evaluasi Lembaga Pondok Pesantren}

Pondok pesantren Nasyrul Ulum dalam merealisasikan evaluasi selain pendidikannya santri, juga mengevaluasi Ustadznya, kurikulum dan mutakhorijinnya melalui musyawarah setiap 2 bulan sekali.

\section{Eksternal.}

Pengurus Pondok Pesantren Ust.

Ah. Miftahur Rijal mengatakan bahwa Membangun Public relations di podok melalui eksternal antara lain:

a. Kegiatan yang langsung berhubungan dengan masyarakat, antara lain :
1) Haul Kyai Mansur;
2) Maulid Nabi;
3) Pembagian daging kurban.

b. Kegiatan yang tidak langsung berhubungan dengan masyarakat antara lain:

1) Pengajian kitab;

2) Pengajian shohih bukhori;

3) Pembacaan rotibul haddad;

4) Pembacaan tahlil dan sholawat.

c. Strategi pemecahan dalam masalah, antara lain :

1) Pesantren melibatkan pihak atau kelompok yang di nilai merugikan pesantren.

2) Membuat program baru yang bertujuan mengoptimalkan peran serta membangun masyarakat.

d. Pengurus Mengadakan evaluasi setiap 1 semester sekali dengan wali santri.

e. Kerjasama dengan Kemenag Kabupaten, Wilayah dan Pusat.

f. Para santri setiap bulan Ramdlan di sebar ke pelosok pelosok desa untuk mengikuti Pratek Lapangan.

g. Kerjasama dengan Media pers.

h. Kerjasama dengan Para Alumni.

Esensi pendidikan pesantren adalah siap hidup bermasyarakat, oleh karena itu suatu lembaga harus berkolaborasi dengan alumni sebagai out poutnya pesantren dan barometer pendidikan maju mundurnya lembaga.

Dengan demikian usaha dan himbauan dimaksudkan agar ada usaha untuk membimbing dan mengembangkan 
potensi santri / anak didik secara optimal, supaya dapat menjadi pengabdi Allah yang setia, dengan mempertimbangkan latar belakang perbedaan individu, tingkat usia, jenis kelamin dan lingkungan masingmasing.

\section{F. ANALISIS}

Melihat teori di atas penulis menganalisis bahwa Public relations di Pondok Pesantren dengan sumber - sumber yang dipaparkan sangatlah baik. Oleh karena itu keberhasilan peran Public relations dalam menunjang fungsi-fungsi manajemen pendidikan untuk mencapai tujuan bersama tergantung pada kemampuan memanfaatkan unsur-unsur sumber daya yang dimiliki pada sebuah organisasi atau lembaga tersebut, artinya sebagai public relations manajer dituntut kemampuannya untuk mengorganisasikan seluruh unsur sumber daya yang ada.

Langkah - langkah membangun Public relations dalam lembaga pendidikan yaitu:

1. Mempunyai Prinsip-Prinsip Manajemen Humas

2. Merealisasikan Program Manajemen Humas

3. Proses Pelaksanaan Tugas Humas

4. Analisis Sumber Daya Manusia

5. Analisis Sumber Daya Keuangan

6. Analisis Sumber Daya Sarpras

7. Analisis Masalah dan Hambatan
8. Analisis Penyelesaian Masalah

Sedangkan langkah - langkah cara membangun Public relations dalam Pondok Pesantrn Nasyrul Ulum Modangan melalui internal dan eksternal.

\section{Membangun Kualitas Santri untuk} menghasilkan out put yang maksimal.

2. Membangun Komunikasi dengan elemen masyarakat.

Dari hasil wawancara atau pengamatan di PP. Nasyrul Ulum Modangan dilihat dari keseluruhan dalam membangun Public relations sangat baik, karena dalam pelaksanaannya telah mempersiapkan yang sesuai dengan perencanaan dan sering adanya evaluasi.

Merujuk dalam pesan baginda Nabi Muhammad.S.A.W. yaitu :

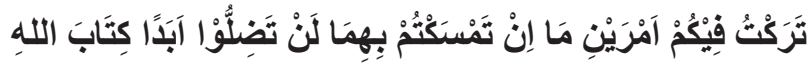

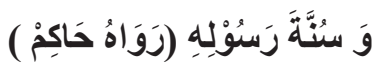 "Telah aku tinggalkan kepada kalian semua dua perkara yang jika kalian berpegang teguh padanya maka tidak akan tersesat selama-lamanya yaitu kitab Allah (Al-Qur'an) dan Sunnah Nabi- Nya." (HR. Hakim)}

Keterangan hadist diatas perlu dipahami dan di realisasikan, sebab dalam membangun Public relations banyak sekali penyimpangan yang tidak seuai ajaran Islam. Oleh sebab itu membangun Public 
relations sangatlah penting mulai plening, organising, actuating dan evalution, tapi tidak meninggalakan etika Islam.

\section{G. PENUTUP}

Berdasarkan teori di atas dapat disimpulkan sebgai berikut :

1. Public Relations merupakan fungsi manajemen yang khas, yang mendukung pembinaan dan pemeliharaan, jalur bersama antara organisasi dan Publik-nya mengenai komunikasi, pengertian dan kerjasama.

2. Pengaruh negatif, mungkin terjadi akibat penyalah gunaan etika dalam kegiatan PR dan pengaruh positif yang dapat ditimbulkan akibat dijalankannya kode etik

3. Langkah - Langkah strategi persuasive dan kontributif dalam membangun Public Relations secara efektif dengan cara meningkatkan kualitas internal dan eksternal. Sehingga Public Relations tetap harmonis baik dengan lembaga dan masyarakat. 


\section{DAFTAR RUJUKAN}

Taufiq, Amir, 2005, Dinamika Pemasaran; Jelajahi dan Rasakan, Jakarta:PT Raja Grafindo Persada

Buchori, Alma, 2008, Manajemen Corporate dan Strategi Pemasaran Jasa Pendidikan; Fokus pada mutu dan layanan prima, Bandung: Alfabeta

Cultip, 2000, Efective Public Relations, Jakarta : PT. INDEKS kelompok gramedia Center

Machali, Imam, 2010, Manajemen Pemasaran Jasa pendidikan madrasah, dalam Antologi Kependidikan Islam: kajian pemikiran pendidikan Islam dan manajemen pendidikan

Islam, Yogyakarta: Jurusan KI Fakultas Tarbiyah

Kusunastuti, Frida, 2001, Dasar-Dasar Humas, Jakarta : Ghalia Indonesia

Majah, Ibnu, 1993, Sunan Ibnu Majah, Beirut: Dar al-Fikri, cet II
Rachman, Abdur, 2001, Dasar-dasar Public Relations. Bandung, Penerbitan PT. Citra Aditya Bakti

Rosyadi, Ruslan, 2008, Manajemen Public Relations dan Media Komunikasi, Jakarta : Rajawali pers

Riantara, YosaI, 2004, Community Relations Konsep dan Aplikasinya, Simbiosa Rekatama Media : Bandung

Kasali, Rhenald, 2003, Manajemen Public Relations Konsep dan Aplikasinya di Indonesia, Jakarta : Pustaka Utama Grafiti

Munzier, Suparta, 2002, Ilmu Hadits, Jakarta:PT. Raja Grafindo Persada

Widjaja, 2004, Transformasi, pendidikan Islam di indonesia; anatomi keberadaan madrasah dan PTAI ,Yogyakarta : Gama Media 